\title{
Separation and Determination of Some Organic Acids in Dry Calyces of Iraqi Hibiscus Sabdariffa Linn
}

\author{
Sarah K.Ibrahim*
}

\author{
Berween A. Hasan** \\ Received 30, March, 2014 \\ Accepted 30, June, 2014
}

Kareem D. Khalaf*

(c) $(1) \Theta(9$

This work is licensed under a Creative Commons Attribution-NonCommercial-
es 4.0 International Licens

NoDerivatives 4.0 International Licens

\begin{abstract}
:
A new reversed phase- high performance liquid chromatographic (RP-HPLC) method with Ultraviolet-Visible spectrophotometry has been optimized and validated for the simultaneous extraction and determination of organic acids present in Iraqi calyces of Hibiscus Sabdraffia Linn. The method is based on using ultrasonic bath for extracting organic acids. Limit of detection in $\mu \mathrm{g} / \mathrm{ml}$ of Formic acid, Acetic acid, Oxalic acid, Citric acid, Succinic acid, Tartaric acid, and Malic acid $126.8498 \times 10^{-6}, 113.6005 \times 10^{-}$ ${ }^{6}, 97.0513 \times 10^{-6}, 49.7925 \times 10^{-6}, 84.0753 \times 10^{-6}, 92.6551 \times 10^{-6}$, and $106.1633 \times 10^{-6}$ ,respectively. The concentration of organic acids found in dry spacemen of calyces of Iraqi Hibiscus Sabdraffia Linn. under study: Formic acid, Acetic acid, Oxalic acid, Citric acid, Succinic acid, Tartaric acid, and Malic acid are $114.896 \mu \mathrm{g} / \mathrm{g}, 64.722$ $\mu \mathrm{g} / \mathrm{g}, 342.508 \mu \mathrm{g} / \mathrm{g}, 126.902 \mu \mathrm{g} / \mathrm{g}, 449.91 \mu \mathrm{g} / \mathrm{g}, 268.52 \mu \mathrm{g} / \mathrm{g}$, and $254.07 \mu \mathrm{g} / \mathrm{g}$ respectively.
\end{abstract}

Key words: Organic acids, Hibiscus Sabdraffia Linn., RPHPLC- Uv/Vis.

\section{Introduction}

Hibiscus Sabdraffia Linn. is a tropical plant and belongs to malvaceae family[1]. The calyces are important part of Hibiscus Sabdraffia Linn. which dried under sun light and air, contain organic acids ( tartaric, citric, malic, and hibiscic) showing high stability under the mentioned drying process[2]. Many phytochemicals have been found to be protective preventive against and many degenerative diseases and pathological processes such as in ageing, coronary heart disease, Alzheimers disease, neurodegenerative disorders, atherosclerosis cataracts, and inflammation [3]. Medical uses of Calyces are a wide, for example, infusion of calyces are regarded as diuretic, choleretic, febrifugal, hypotensive, decreasing the viscosity of blood and stimulating intestinal peristalsis [4], reduce hypertenstion [5]. Infusions of calyces are used as antiseptic, aphrodisiac, astringent, cholagogue, demulcent, diuretic, emollient, purgative, refreshment, sedative, stomachic, and tonic, traditionally [6]. The red calyces contain oxalic acid, tartaric acid, citric acid, malic acid [7].

Organic acids are typical products of microbial metabolism. All organic acids occur naturally in a variety of vegetable and animal substrates and can, therefore, be either naturally present as constituents of foods as a result of normal biochemical metabolic processes[8]. Among phytochemicals, organic acids may contribute to the protection against various diseases, due to the antioxidant potential [9]. Organic acids are such effective food preservatives because, apart from their antimicrobial inhibitory activities, they also act as acidulants and in so doing reduce bacterial growth by lowering the $\mathrm{pH}$ of

*Department of Chemistry, College of Science for Women, University of Baghdad (Iraq).

$* *$ Ministry of Education (Iraq). 
food products to levels that inhibit bacterial growth [10-11].

The literature reviews, show that several methods have been developed for the determination of organic acids, spectrophotometric[1213], enzymatic method[14], gas chromatography[15-17], capillary zone electrophoresis[18-22], and HPLC[2327]. All the above method publications concentrated on the determination of organic acids in fruits and different beverages. There is no any publication about the simultaneous separation, qualitative, and quantitative determination of carboxylic acids in calyces by HPLC technique; so, we believe that the proposed method is the first procedure for the determination of the organic acids showed in Fig.1<smiles>CC(=O)O</smiles>

1.Acetic acid<smiles>O=C(O)CCC(=O)O</smiles>

2.Formic acid<smiles>O=CO</smiles>

3.Succinic acid<smiles>O=C(O)CC(O)(CC(=O)O)C(=O)O</smiles>

4.Citric acid<smiles>O=C(O)CC(O)C(=O)O</smiles>

5.Malic acid<smiles>O=C(O)C(=O)O</smiles>

6.Oxalic acid<smiles>O=C(O)C(O)C(O)C(=O)O</smiles>

7.Tartaric acid

Fig.1: Structure of organic acids under study.

\section{Materials and Methods:}

\section{HPLC Analysis.}

The quantitative and qualitative analysis of organic acids were performed using Shimadzu HPLC system model LC-6A equipped with a binary pumps as solvent delivery model LC-10A from Shimadzu Corporation. The system is equipped with a Shimdzu SPD-6A ultraviolet visible variable wave length (190-800 $\mathrm{nm})$ detector. $20 \mu \mathrm{l}$ samples was injected, and the chromatographic separation was performed on a $\mathrm{RP}-\mathrm{C}_{18}$ Shimpack IC-A1 $(3 \mu \mathrm{m})$ column, $50 \mathrm{~mm} \times 4.6 \mathrm{~mm}$. After optimizing the instrumental and sample parameter, the HPLC analysis condition for the sample were $1.2 \mathrm{mM}$ Potassium hydrogen phosphate at $\mathrm{pH} 4.5$ as mobile phase, $1.0 \mathrm{ml} / \mathrm{min}$ as flow rate, and using $210 \mathrm{~nm}$ as maximum wavelength.

\section{Chemicals.}

All chemical reagents used for analysis organic acids were analytical Grade (99.99\%) of BDH Company. The reagents include Potassium hydrogen phosphate, Deionized water, and Methanol. Standards of (1) acetic acid (99\%), (2) formic acid (98\%), (3) succinic acid (98\%), (4) citric acid (99.8\%), (5) malic acid (99.8\%), (6) oxalic acid (99.9\%), and (7) tartaric acid (99.9\%) were purchased from BDH Company.

\section{Hibiscus Sabdariffa Linn. sample.}

Fresh Hibiscus Sabdariffa Linn. fruits were harvested from Baghdad, Iraq. After harvesting the fruits were washed with deionized water three times to clean them from dust, then seeds were 
removed to obtain fresh Hibiscus Sabdariffa Linn. calyces. The calyces were dried at a room temperature for 7 days and then they Dried were immediately packed in polyethylene jars. Thereafter, the calyces also dried again in oven at $35 \mathrm{C}^{\circ}$ for three hours until constant weight. The dried calyces were grounded for $10 \mathrm{~min}$ using Agate mortar. The sample powder were immediately packed in polyethylene jars and kept in refrigerator until used.

\section{Preparation of Standard Solution.}

A standard stock solution of 1000 ppm of each organic acid was prepared by dissolving $(1 \mathrm{~g})$ in $1000 \mathrm{ml}$ deionized water. A working standard solution of $25 \mathrm{ppm}$ was prepared. For studying the optimization parameters, a standard working solution containing all organic acids with stable concentration was prepared.

\section{Extraction Procedure.}

Calyces liquid extracts were carried out by using deionized water: methanol solutions in different ratio, Table (1), were used for the extraction. Calyces powder (1 g) was placed in glass beakers, and $10 \mathrm{ml}$ of extracting agent was added. The beakers were placed in the Ultra sonic bath (supplied from Karl Kolb, Germany) for $15 \mathrm{~min}$, and then the mixtures were allowed to stand for $5 \mathrm{~min}$. The supernatant was filtered through Whatman paper No.2 followed through micro filter $(0.45$ $\mu \mathrm{m})$. The filtrate was kept in the glass tubes and preserved in refrigerator at 8 $\mathrm{C}^{\circ}$.

Table (1) Deionized water- methanol ratio used in extraction.

\begin{tabular}{|c|c|c|}
\hline \multirow{2}{*}{ Samples } & \multicolumn{2}{|c|}{ Deionized water- methanol ratio } \\
\cline { 2 - 3 } & Deionized water\% & Methanol\% \\
\hline Sample 1 & 100 & 0 \\
\hline Sample 2 & 80 & 20 \\
\hline Sample 3 & 60 & 40 \\
\hline Sample 4 & 50 & 50 \\
\hline Sample 5 & 40 & 60 \\
\hline Sample 6 & 20 & 80 \\
\hline Sample 7 & 0 & 100 \\
\hline
\end{tabular}

\section{Results and Discussion:}

\section{Optimization Conditios}

\subsection{The Effect of $\mathrm{pH}$.}

The effect of $\mathrm{pH}$ of mobile phase in RP-HPLC for the separation a mixture of seven carboxylic acids were intensively studied. To five volumetric flasks $(25 \mathrm{~mL})$, containing $25 \mathrm{ppm}$ of each carboxylic acid understudy, 1.2 $\mathrm{mM}$ potassium hydrogen phosphate ( $\mathrm{pH} 2.5$ ) was added, $0.5 \mathrm{M}$ potassium hydroxide (1, 2, 3 and $4 \mathrm{~mL})$ added to four volumetric flasks and added to all volumetric flasks deionized water to complete the volume and obtain $\mathrm{PH}$ $(2.5,3.5,4.5,5.5$ and 6.5$)$ respectively. The results obtained are shown in Table 2.

Table 2: Controlling of $\mathrm{pH}$ of mobile phase.

\begin{tabular}{|c|c|c|c|}
\hline Organic acid & $P H$ & $\begin{array}{l}\text { Retention time } \\
\text { (min.) }\end{array}$ & $\begin{array}{c}\text { Peak area } \\
(\mu \nu)\end{array}$ \\
\hline \multirow{5}{*}{ Acetic acid } & 2.5 & 4.512 & 26291 \\
\hline & 3.5 & 3.493 & 22678 \\
\hline & 4.5 & 2.98 & 32062 \\
\hline & 5.5 & 2.007 & 43261 \\
\hline & 6.5 & 0.987 & 44451 \\
\hline \multirow{5}{*}{ Formic acid } & 2.5 & 5.975 & 28454 \\
\hline & 3.5 & 4.39 & 22160 \\
\hline & 4.5 & 3.823 & 30850 \\
\hline & 5.5 & 3.018 & 47749 \\
\hline & 6.5 & 2.152 & 45240 \\
\hline \multirow{5}{*}{ Succinic acid } & 2.5 & 7.147 & 28050 \\
\hline & 3.5 & 5.573 & 21055 \\
\hline & 4.5 & 5.155 & 24380 \\
\hline & 5.5 & 3.5 & 52595 \\
\hline & 6.5 & 2.82 & 46331 \\
\hline \multirow{5}{*}{ citric acid } & 2.5 & 9.95 & 32802 \\
\hline & 3.5 & 7.823 & 15265 \\
\hline & 4.5 & 6.075 & 23182 \\
\hline & 5.5 & 4.163 & 47939 \\
\hline & 6.5 & 3.882 & 51452 \\
\hline \multirow{5}{*}{ Malic acid } & 2.5 & 10.97 & 36143 \\
\hline & 3.5 & 9.805 & 16817 \\
\hline & 4.5 & 7.333 & 28191 \\
\hline & 5.5 & 5.845 & 54743 \\
\hline & 6.5 & 4.97 & 65344 \\
\hline \multirow{5}{*}{ Oxalic acid } & 2.5 & 12.962 & 24384 \\
\hline & 3.5 & 11.068 & 19045 \\
\hline & 4.5 & 8.415 & 28783 \\
\hline & 5.5 & 6.84 & 49044 \\
\hline & 6.5 & 5.95 & 58692 \\
\hline \multirow{5}{*}{ Tartaric acid } & 2.5 & 13.98 & 31473 \\
\hline & 3.5 & 11.87 & 20450 \\
\hline & 4.5 & 8.982 & 25635 \\
\hline & 5.5 & 7.232 & 56334 \\
\hline & 6.5 & 6.312 & 75565 \\
\hline
\end{tabular}

Table 2 and Figure 2 show obviously that reversed phase separation can be 
performed successfully at low $\mathrm{pH}$ value, because the low $\mathrm{pH}$ results is good solubility of the sample components and formation anions of organic acid molecules ( $\mathrm{RCOO}^{-}$) and form ion suppression of residual silanol groups on the silica matrix. The
pH 4.5 was selected as the best one because in this medium of mobile phase with $\mathrm{PH} 4.5$, it typically ensures the proper interaction of analytes with the non-polar, hydrophobic particle surface of $\mathrm{C}_{18}$ bonded silica (ODS) column.

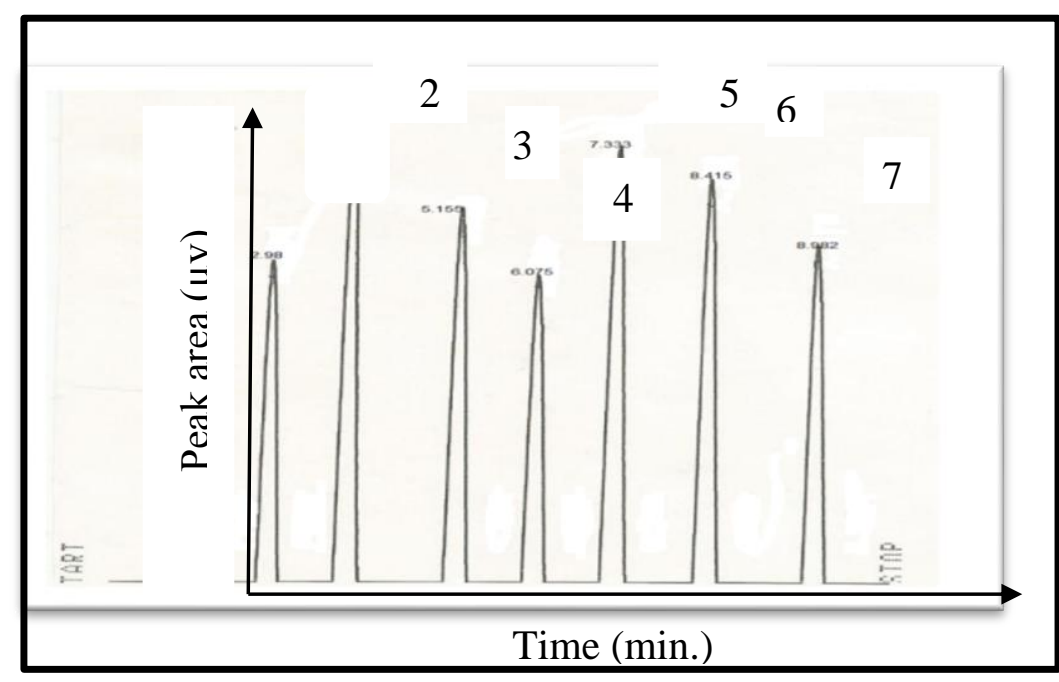

Fig. 2: Typical chromatogram of separating of organic acids in $\mathrm{pH} 4.5$, the sequence of the peaks is as follow: 1 . acetic acid, 2 . formic acid, 3 . succinic acid, 4. citric acid, 5. malic acid, 6. oxalic acid, and 7. tartaric acid.

The retention time data at different $\mathrm{pH}$ values between (2.5-6.5) show that, the organic acids have high retention time at low $\mathrm{pH}(2.5)$ due to the presence of undissociated $\mathrm{COOH}$, So that the retention decreases with increasing the $\mathrm{pH}$ values, and when the $\mathrm{pH}$ and PI (Isolectric point) become coincident a local minimum occurs.

Fig. 3 shows that the relationship between the peak area and $\mathrm{pH}$ values which explain the general approach to the separation of the mixture containing an ionizable carboxylic acids is to suppress their ionization. Suppression of the ionization decreases a power of the molecular salvation and exposes the hydrophobic (organic) part of the molecule to the surface interaction. Ionization suppression is usually made by the adding of a buffer into the solvent which shift a PH to the certain value.

In the absence of the buffer, easy ionizable compounds are eluted from the column as very broad peaks, so, it was found that high $\mathrm{pH}$ values cause broad and tailed peaks, so, the peak area increased, and for these reason, $\mathrm{pH} 4.5$ provides a good separation which can be noticed from the symmetrical shape of the peaks as well as good resolution. 


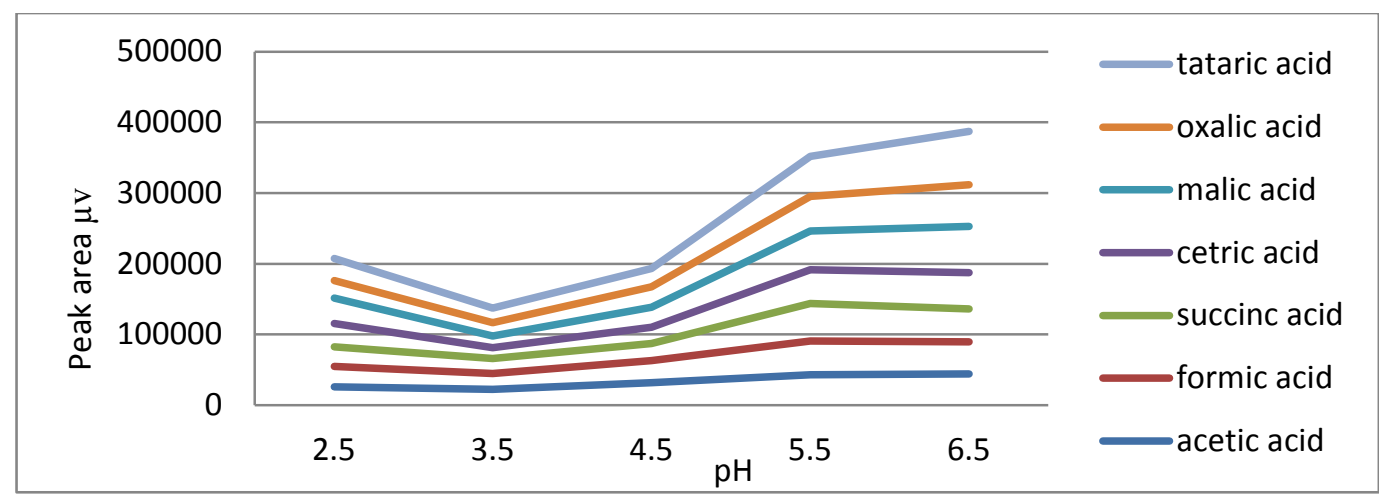

Fig. 4: The Effect of pH on peak area of organic acids separation using phosphate buffer solution.

\subsection{Optimization of Flow Rate}

Flow rate impacts HPLC system pressure chromatographic quality and analysis time. So, one must choose a flow rate that is appropriate for HPLC system and column. A higher than usual flow rate may adversely affects the quality of the chromatography not giving the analyte sufficient time to interact with the stationary phase. Faster is not always better. A lower than usual flow rate may leave the analyte waiting for the peak to appear at the detector. Therefore, the effects of flow rate were intensively studied as shown in Table 3.

Fig. 4 shows retention time and peak area as a function of flow rate of $1 \mathrm{ml} \cdot \mathrm{min}^{-1}$ which demonstrates quite obviously a typical separation and resolution of carboxylic acids was achieved and leads to decrease solvent consumption and decrease in run time.
Table 3: The Effect of flow rate on retention time and peak area.

\begin{tabular}{|c|c|c|c|}
\hline $\begin{array}{c}\text { Organic } \\
\text { acids }\end{array}$ & $\begin{array}{l}\text { Flow rate } \\
\left({\left.\mathrm{ml} . \mathrm{min}^{-1}\right)}^{-1}\right.\end{array}$ & $\begin{array}{l}\text { Retention } \\
\text { time (min.) }\end{array}$ & $\begin{array}{c}\text { Peak area } \\
(\mu v)\end{array}$ \\
\hline \multirow{5}{*}{ Acetic acid } & 0.6 & 1.733 & 92691 \\
\hline & 0.8 & 1.59 & 66931 \\
\hline & 1.0 & 1.398 & 59279 \\
\hline & 1.2 & 1.237 & 33145 \\
\hline & 1.4 & 1.133 & 47675 \\
\hline \multirow{5}{*}{$\begin{array}{c}\text { Formic } \\
\text { acid }\end{array}$} & 0.6 & 2.568 & 94464 \\
\hline & 0.8 & 2.427 & 56625 \\
\hline & 1.0 & 2.22 & 41765 \\
\hline & 1.2 & 2.073 & 27486 \\
\hline & 1.4 & 1.985 & 35545 \\
\hline \multirow{5}{*}{$\begin{array}{l}\text { Succinic } \\
\text { acid }\end{array}$} & 0.6 & 3.895 & 129953 \\
\hline & 0.8 & 3.742 & 60811 \\
\hline & 1.0 & 3.557 & 31193 \\
\hline & 1.2 & 3.405 & 29324 \\
\hline & 1.4 & 3.297 & 31941 \\
\hline \multirow{5}{*}{ Citric acid } & 0.6 & 4.825 & 113099 \\
\hline & 0.8 & 4.667 & 46255 \\
\hline & 1.0 & 4.475 & 39149 \\
\hline & 1.2 & 4.322 & 41719 \\
\hline & 1.4 & 4.223 & 23420 \\
\hline \multirow{5}{*}{ Malic acid } & 0.6 & 6.072 & 107084 \\
\hline & 0.8 & 5.98 & 40154 \\
\hline & 1.0 & 5.73 & 32164 \\
\hline & 1.2 & 5.587 & 35882 \\
\hline & 1.4 & 5.48 & 43224 \\
\hline \multirow{5}{*}{$\begin{array}{c}\text { Oxalic } \\
\text { acid }\end{array}$} & 0.6 & 7.145 & 102385 \\
\hline & 0.8 & 6.978 & 35002 \\
\hline & 1.0 & 6.815 & 31433 \\
\hline & 1.2 & 6.662 & 25571 \\
\hline & 1.4 & 6.555 & 29586 \\
\hline \multirow{5}{*}{$\begin{array}{l}\text { Tartaric } \\
\text { acid }\end{array}$} & 0.6 & 7.717 & 98943 \\
\hline & 0.8 & 7.583 & 38271 \\
\hline & 1.0 & 7.387 & 33574 \\
\hline & 1.2 & 7.235 & 29792 \\
\hline & 1.4 & 7.148 & 29968 \\
\hline
\end{tabular}




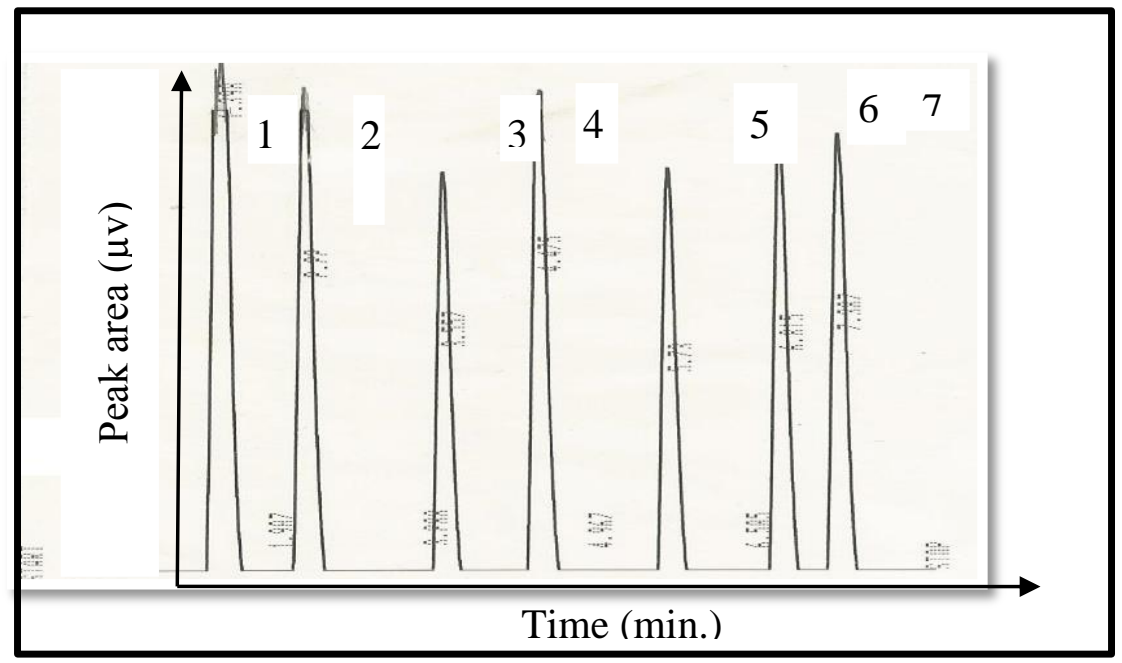

Fig. 4: Typical chromatogram of separation organic acids using a flow rate of 1 ml.min ${ }^{-1}$, the sequence of the peaks is as follow: 1 . acetic acid, 2 . formic acid, 3 . succinic acid, 4. citric acid, 5. malic acid, 6. oxalic acid, and 7. tartaric acid.

Fig. 5 shows the relationship between the peak area as a function of flow rate which confirms once again what has been achieved in Figure 6 that the flow rate of $1 \mathrm{ml} \cdot \mathrm{min}^{-1}$ is the most appropriate flow rate because at lower flow rate lower than $1 \mathrm{ml} \cdot \mathrm{min}^{-1}$ the area of each peak is very high and seem to be out of scale while at flow rate higher than $1 \mathrm{ml} \cdot \mathrm{min}^{-1}$, the area of each peak decreased dramatically, so the selection a flow rate of 1 ml.min ${ }^{-1}$ ensures stable base line, good resolution and retention time.

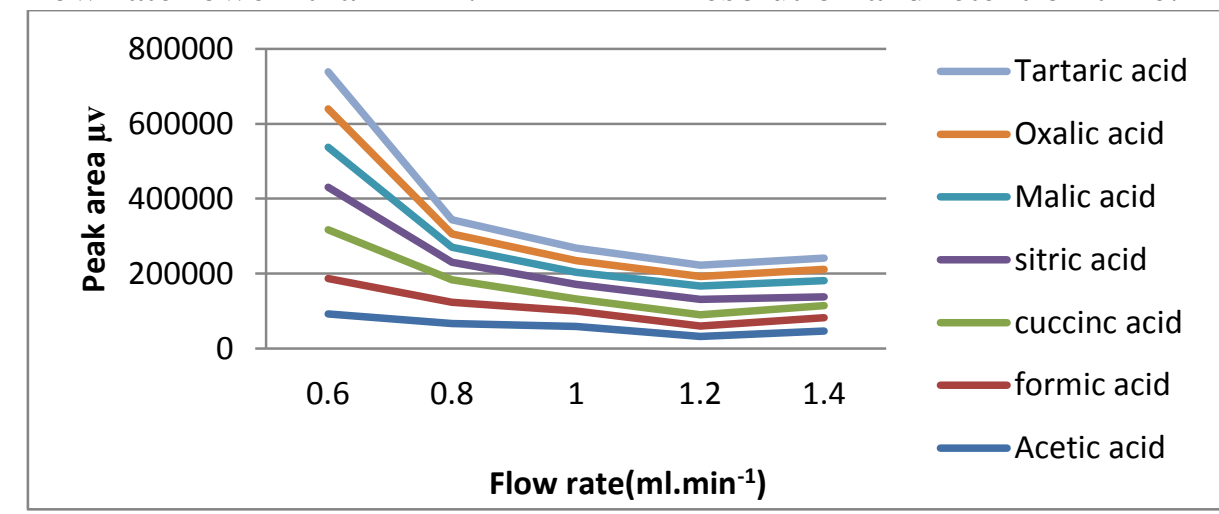

Fig. 7: The Effect of flow rate on separation organic acids as a function of peak area.

\subsection{The Effect of Extraction Mixture on Extraction of Organic acids.}

Seven kinds of solvent extracts from calyces of H. Sabdraffia Linn. were used to examine the effects of extraction solvent mixtures on organic acid concentration. All calyx extracts are rich source in organic acids but the best extraction occurs in $60 \%$ deionized water: $40 \%$ methanol as extraction agent. Figure 8 shows the best separation. 


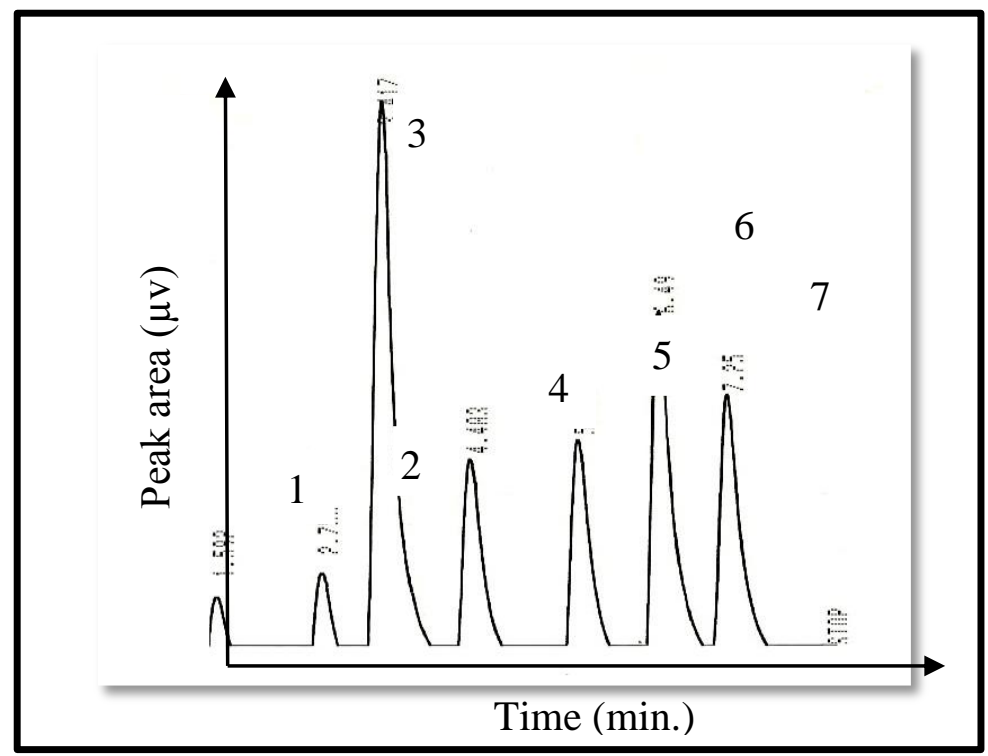

Fig. 8: Best separation of organic acids in calyces sample.

According to the above figure, the retention times, and the sequence of the peaks is as follow: 1. Acetic acid, 2. Formic acid, 3. Succinc acid, 4. Citric acid, 5. Malic acid, 6. Oxalic acid, and 7. Tartaric acid

\section{Validation Method:}

The validation study for acetic acid, formic acid, succinic acid, citric acid, malic acid, oxalic acid, and tartaric acid using RP-HPLC-UV/Vis was performed under the optimized conditions at $210 \mathrm{~nm}$ as maximum wavelength, $1.0 \mathrm{ml} / \mathrm{min}$ as flow rate of mobile phase, and $1.2 \mathrm{mM}$ Potassium hydrogen phosphate at $\mathrm{pH} 4.5$ as a mobile phase during analysis time ( 8 minutes).

\section{Linearity and Limit of Detection (LOD).}

Six standards solutions of organic acids were prepared in the following concentration: $0.78,1.62,3.25,6.25$, 12.5 , and $25 \mathrm{in} \mu \mathrm{g} / \mathrm{mL}$. The calibration curve obtained by plotting the peak area of chromatograms for Organic acids against the concentration, with three replicates $(n=3)$. Table 4 shows the validation of analytical method obtained from the calibration curves of organic acids analysed on RP-HPLC$\mathrm{UV} / \mathrm{V}$ is with the linearity range $(0.78$ $25 \mu \mathrm{g} / \mathrm{mL}$ )

Table 4: Validation of analytical method for organic acids by RP-HPLC-UV/Vis.

\begin{tabular}{|c|c|c|c|c|c|}
\hline Organic acids & Linear equation & $\boldsymbol{R}^{2}$ & LOD in $\boldsymbol{p p m}$ & $\begin{array}{c}\boldsymbol{R S D \%} \\
\boldsymbol{n}=3\end{array}$ & $\begin{array}{c}\text { Sensitivity } \\
\text { in } \boldsymbol{\mu v} \text { ppm }\end{array}$ \\
\hline Formic acid & $\mathrm{Y}=2270.4 \mathrm{x}+4535.8$ & 0.9953 & $126.8498 \times 10^{-6}$ & 0.009965 & 2270.4 \\
\hline Acetic acid & $\mathrm{Y}=2535.2 \mathrm{x}+5534.7$ & 0.9955 & $113.6005 \times 10^{-6}$ & 0.010458 & 2535.2 \\
\hline Oxalic acid & $\mathrm{Y}=2967.5 \mathrm{x}+644.19$ & 0.9994 & $97.0513 \times 10^{-6}$ & 0.010604 & 2967.5 \\
\hline Citric acid & $\mathrm{Y}=5784 \mathrm{x}-108.36$ & 0.9981 & $49.7925 \times 10^{-6}$ & 0.005536 & 5784 \\
\hline Succinc acid & $\mathrm{Y}=3425.5 \mathrm{x}+5218.6$ & 0.9973 & $84.0753 \times 10^{-6}$ & 0.008316 & 3425.5 \\
\hline Tartaric acid & $\mathrm{Y}=3108.3 \mathrm{x}+3187.7$ & 0.9932 & $92.6551 \times 10^{-6}$ & 0.007801 & 3108.3 \\
\hline Malic acid & $\mathrm{Y}=2712.8 \mathrm{x}+2088.9$ & 0.993 & $106.1633 \times 10^{-6}$ & 0.011569 & 2712.8 \\
\hline
\end{tabular}




\section{Mean concentration of organic acids in Calyces of Iraqi Hibiscus Sabdraffia Linn.}

Table 4 shows the mean concentration of organic acids for the best separation from the calyces extract in ratio $(60 \%$ deionized water: $40 \%$ methanol). Triplicate measurement was done on the best extract sample.

Table 4: Mean concentration of organic acids.

\begin{tabular}{|c|c|}
\hline Organic Acid & $\begin{array}{c}\text { Mean concentration } \\
\mathbf{\mathbf { S D }} \text { (ppm) }\end{array}$ \\
\hline Formic acid & $11.4896 \pm 2.0$ \\
\hline Acetic acid & $6.4722 \pm 1.9$ \\
\hline Oxalic acid & $34.2508 \pm 2.1$ \\
\hline Citric acid & $12.6902 \pm 2.2$ \\
\hline Succinc acid & $44.991 \pm 1.8$ \\
\hline Tartaric acid & $26.852 \pm 1.7$ \\
\hline Malic acid & $25.7035 \pm 2.0$ \\
\hline
\end{tabular}

3. Concentration of Organic acids in Dry Spacemen of Calyces of Hibiscus Sabdraffia Linn.

Table 5 shows the concentrations of the substances which was studies by this research in the dry spacemen of calyces.

Table 5: Concentration of organic acids.

\begin{tabular}{|c|c|}
\hline Substance & Concentration $(\boldsymbol{\mu g} / \mathbf{g})$ \\
\hline Formic acid & 114.896 \\
\hline Acetic acid & 64.722 \\
\hline Oxalic acid & 342.508 \\
\hline Citric acid & 126.902 \\
\hline Succinc acid & 449.91 \\
\hline Tartaric acid & 268.52 \\
\hline Malic acid & 254.07 \\
\hline
\end{tabular}

\section{Interference study}

To investigate effect of other organic acids on measurements, standard addition method was carried out. It was observed that lactic acid ( $2 \mathrm{mg} / \mathrm{mL}$ ), propanoic acid $(1 \mathrm{mg} / \mathrm{mL})$, valeric acid ( $2 \mathrm{mg} / \mathrm{mL}$ ), fumaric acid( $2 \mathrm{mg} /$ $\mathrm{mL}$ ), and benzoic acid( $2 \mathrm{mg} / \mathrm{mL}$ ) did not affect the measurement of the acids under study and showed a different retention time.

\section{Conclusions}

The proposed analytical method by RP- HPLC- Uv/ Vis for simultaneous separation and determination of seven organic acids naturally present in Hibiscus sabdraffia calyces was highly convenient for evaluation the level concentration of the compounds under study. The obtained results show also, that the Iraqi Hibiscus Sabdraffia calyces are rich in these compounds.

\section{References}

1. Odebunmi, E. O.; Dosunmu, O. O. and Jedede, E. A. 2002. Biophysico-chemical Analysis and Fermentation Studies of Hibiscus Sabdariffa, NJS. 30(1): 1-8.

2. Meza-Jiménez, J., J. Ramírez, G. Luna-Solano, and I. GonzálezAndrade. 2009. Low-cost solar thermodynamics drying system for the dehydration of Roselle (Hibiscus Sabdrariffa L.). DRY TECHNOL. 27: 621-624.

3. Ijeomah, A. U., Ugwuona, F. U. and Abdullahi, H., 2012, Phytochemical composition and antioxidant properties of hibiscus sabdariffa and moringa oleifera, NJAFE, 8: 10-16.

4. Morton, J. 1987. Roselle. p. 281286. In: Fruits of warm climates. Julia F. Morton, Miami, FL.

5. Christian, K. R.; Nair, M. G and Jackson, J. 2006. Antioxidant and cyclooxygenase inhibitory activity of sorrel (Hibiscus sabdariffa), JFCA. 19: 778-783.

6. Ali BH, Al-Wabel NA and Blunden G. 2005. Phytochemical, pharmacological and toxicological aspects of Hibiscus sabdariffa L.: a review, Phytother Res. 19: 369-375.

7. Vilasinee H, Anocha U, Noppawan PM, Nuntavan B, Angkana $\mathrm{H}$ and Chuthamanee S., 2005, Antioxidant Effect of aqueous extracts from dried calyces of Hibiscus sabdariffa L. (Roselle) in vitro using rat low- 
density lipoprotein (LDL), Biol Pharm Bull, 28: 481-484.

8. Gomis, D.B., 1992, HPLC analysis of organic acids. In: L.M.L. Nollet (Ed.), Food Analysis by HPLC, New York: Marcel Dekker, pp. 371-385.

9. Silva, B. M.; Andrade, P. B.; Valenta o, P.; Ferreres, F.; Seabra, R. M.; and Ferreira, M.A., 2004, Quince (Cydonia oblonga Miller) fruit (pulp, peel, and seed) and jam: antioxidant activity, Food Chem., 52: 4705-4712.

10. Dziezak, J.D., 1990, Acidulants: Ingredients that do more than meet the acid test, Food Technology, 44:78-83.

11. Hinton, A., Jr., 2006, Growth of Campylobacter in media supplemented with organic acids, JFP, 69:34-38.

12. Rebelein, H., 1961, Colorimetric determination of tartaric and lactic acids in wine and fruit juice, Deutsche bebensmittel- Rundschau, 57: 6-41.

13. Vereda, E.; Garcia de torres, A.; Rivero, A.; and Cano, J.M., 1998, Determination of organic acids in wine. A review., Quimica Analitica, 17: 167-175.

14. Puchades, R.; Herrero, M.A.; Maquieria A.; and Atienza, J., 1991, Simultaneous enzymatic determination of L-malic acid and L-lactic acid in wine by flow injection analysis, Food Chem., 42:67-182.

15. Cocchi, M.; Durante, C.; Grandi, M.; Lambertini, P.; Manzini, D.; and Marchetti, A., 2006, Simultaneous determination of sugar and organic acids in aged vinegars and chemometric data analysis, Talanta, 69(5):1166-1175.

16. Kovacs, A.; Mort,M.; and Kende, A., 2011, Development and optimization of a method for the analysis of phenols and chlorophenols from aqueous samples by gas chromatographymass spectrometry after solid-phase extraction and trimethylsilylaction, Microchemical J., 99:125-131.

17. West, E.M.; Mauer, J.L., 2011, Development of an intergrated approach for the stability testing of flavonoids and ascorbic acid in powders, Food Chem., 129:51-58.

18. Cortacero-Ramirez, S.; SeguraCarretero, A.; Decastro, M.H.B.; and Fernandez-Cutierez A., 2005, Determination of low-molecularmass organic acids in any type of beer samples by coelectro osmotic capillary electrophoresis, J. of chromatography A., 1064:115-119.

19. Mato, I.; Huidobro, J.F; SimalLozano, J.; and Sancho, M.T., 2006, Simultaneous determination of organic acids in beverages by capillary zone electrophoresis, Analytica Chimica Acta, 565(2): 190-197.

20. Dabek-Ziotorzynska E.; and Mc Grath M., 2000, Determination of low-molecular-weight carboxylic acids in the ambient air and vehicle emissions: a review. Fresenius J. Anal.Chem., 367(6): 507-518.

21. Xiaohua H.; Tohn A.L., Manuel J.G.; and Richard N.Z., 1989, Quantitative determination of low molecular weight carboxylic acids by capillary zone electrophoresis, conductivity detection, Anal. Chem.., 61(7): 766-770.

22. De Barker B.L.; and Nagels L.J., 1996, Potentiometric detection for capillary electrophoresis: Determination of organic acids, Anal. Chem., 68(24):4441-4445.

23. Noriyuki N.; Toshio K.; Tsuguchika Y.; Atsuhiro U.; and Chie N., 1988, 1-pyrenyldiazo methane as a fluorescent labeling reagent for liquid chromatography determination of carboxylic acids, Anal. chem., 50(19): 2067-2070. 
24. Hyoung S.L., 1993, HPLC method for separation and determination of nonvolatile organic acids in orange juice, J. Agric. Food chem., 41(11): 1991-1993.

25. E. Falque Lopez, and E. Fernandeez Gomez, 1995, Simultaneous determination of the major organic acids, sugars, glycerol and ethanol by HPLC in grape mutsts and white wine, J. of chromatographic Sci., 34(5): 254256.
26. Klaus F., 2002, Environmental analysis of aliphatic carboxylic acids by ion-exclusion chromatography, Analytica chemica Acta, 465(1-2):157-173.

27. A. Escobal, J.; Gonzalez, C. Lriondo; and C. Labora, 1997, Liquid chromatographic determination of organic acids in txakoli from Bizkaia, Food chem., 58(4): 381-384.

\section{فصل وتقدير بعض الحوامض العضويه في زهره نبات الكجرات العراقي الجافه

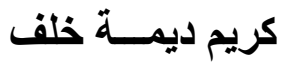 \\ بروين أحمد حسن* \\ سارة خالد ابراهيم \\ قسم الكيمياء، كلية العلوم للبنات، جامعة بغداد

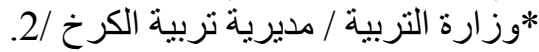

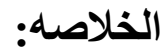

طريقة كرمونوغر افيا السائل عالية الأداء- طور معاكس الجديدة (RP-HPLC) مع مطيافية الأشعة فوق

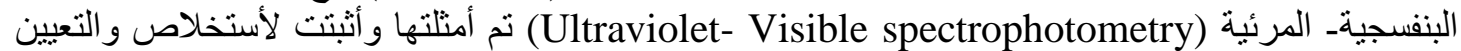
في وقت واحد الحو امض العضوية الموجودة في زهرة نبات الكجر ات العر اقية.

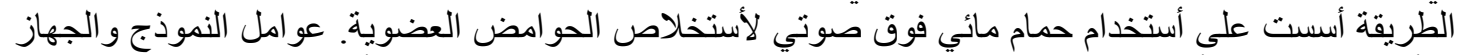

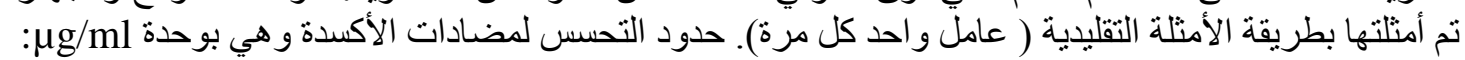
Formic acid, Acetic acid, Oxalic acid, Citric acid, Succinic acid, Tartaric acid, and Malic acid $126.8498 \times 10^{-6}, 113.6005 \times 10^{-6}, 97.0513 \times 10^{-6}, 49.7925 \times 10^{-6}, 84.0753 \times 10^{-6}$, $92.6551 \times 10^{-6}$, and $106.1633 \times 10^{-6}$ respectively

$$
\text { تركيز الحوامض العضوية التي تم در استها لنموذج زهرة نبات الكجرات الجافة هي كالاتي: }
$$

Formic acid, Acetic acid, Oxalic acid, Citric acid, Succinic acid, Tartaric acid, and Malic acid are $114.896 \mu \mathrm{g} / \mathrm{g}, 64.722 \mu \mathrm{g} / \mathrm{g}, 342.508 \mu \mathrm{g} / \mathrm{g}, 126.902 \mu \mathrm{g} / \mathrm{g}, 449.91 \mu \mathrm{g} / \mathrm{g}$, $268.52 \mu \mathrm{g} / \mathrm{g}$, and 254.07 respectively.

$$
\text { الكلمات المفتاحية: حو امض عضوية، نبات الكجرات. }
$$

